Acta vet. scand. $1964,5,56-73$.

From the Department of Surgery and Department of Clinical

Biochemistry, Royal Veterinary College, Stockholm, Sweden.

\title{
RENAL FUNCTION IN DOGS WITH PYOMETRA
}

3. GLOMERULAR FILTRATION RATE, EFFECTIVE RENAL PLASMA FLOW, AND THE RELATION BETWEEN SOLUTE EXCRETION RATE AND MAXIMUM URINE OSMOLARITY DURING DEHYDRATION

By

Åke Åsheim

In bitches with pyometra (chronic purulent endometritis) the ability of the kidneys to excrete concentrated urine is impaired with polyuria and polydipsia as a result ( $\AA$ sheim $1963 \mathrm{~b}$ ). Since the limitation in concentrating ability cannot be ascribed to extrarenal causes (insufficiency of the hypothalamic-hypophyseal system, Åsheim 1963 a), it can fairly confidently be assumed to be of renal origin.

Renal disease of whatever cause can lead to a reduction in the number of functioning nephrons. The residual functioning nephrons assume a greater excretory burden and because of this a greater osmotic load per nephron. This counterbalances the obligatory water resorption in the proximal tubules and results in so-called osmotic diuresis (Bricker et al. 1960, Kleeman et al. 1960). The osmotic diuresis is combined with a reduction of maximum urine osmolarity (max. Uosm) which is not affected by exogenous antidiuretic hormone (West \& Rapoport 1950, Page \& Reem 1952, Zak et al. 1954, Dorhout Mees 1959). As the osmotic load increases, max. Uosm gradually decreases until it approaches plasma osmolarity (Posm).

Renal damage has been reported in bitches with pyometra (Bloom 1954). One has to take into account the possibility that the functioning renal mass can be reduced to such a degree to 
give an osmotic diuresis which can explain the reduction of max. Uosm and the polyuria in conjunction with pyometra.

The present report is concerned with renal clearance studies on bitches with pyometra to ascertain first, whether there is a reduction in functioning renal mass and secondly, whether an osmotic diuresis, i. e. an increase in the rate of solute excretion calculated per unit functioning renal mass, can wholly or partially explain the impaired concentrating ability.

\section{MATERIALS AND METHODS}

The studies were carried out on 46 bitches with pyometra and 15 normal bitches aged between one and five years (mean two years) and weighing between 17 and $26 \mathrm{~kg}$ (mean $21 \mathrm{~kg}$ ). The diagnosis of pyometra was based on the clinical signs and confirmed by histological examination of the uterus. Only bitches with an anamnesis of increased thirst developing in conjunction with the other clinical signs of pyometra were utilized. Bitches in a very poor general condition were not included. The pyometra bitches used for these studies were between three and twelve years old (mean eight years) and weighed between 11 and $42 \mathrm{~kg}$ (mean $23 \mathrm{~kg}$ ).

The renal function tests were carried out on hydrated and dehydrated dogs.

A. Studies on hydrated dogs.

Glomerular filtration rate (GFR) and effective renal plasma flow (ERPF) were determined for 16 bitches with pyometra and for ten normal bitches. The animals were first given water orally and then a positive water balance maintained throughout the course of the inulin and PAH clearance studies by giving hypotonic glucose solution as an intravenous infusion.

B. Studies on dehydrated dogs.

1. Max. Uosm, solute excretion rate and GFR were determined for bitches with pyometra and for normal bitches.

Water was withheld for 21 to 24 hours, ADH administered, and for each animal - 28 with pyometra and 15 normal - the urine formed during each of the last five hours of dehydration (to be referred to as 60-minute periods) was collected in graduated vessels. Uosm was determined for each sample and the highest value obtained for each animal was taken as max. Uosm. 
Urine volume was determined for each period for calculation of solute excretion.

GFR for four of the pyometra bitches was determined from endogenous creatinine clearance during the 60-minute periods. For the other animals GFR was determined immediately after the last of the 60 -minute periods by measuring inulin clearance at the same time as increasing amounts of a hypertonic mannitol solution with sodium chloride added to stimulate diuresis was given intravenously. The value obtained for GFR has been assumed to be identical with the GFR during the 60-minute periods.

When these studies were completed ovariohysterectomy was carried out on the pyometra bitches. Renal function for 13 of these animals was assessed again in the same manner on one or more occasions postoperatively.

2. Changes in max. Uosm during increased osmotic diuresis were followed in normal bitches.

A total of 22 experiments, 15 of them in conjunction with the experiments described under B 1 , were made on the 15 normal bitches dehydrated for 24 hours. Continuously increasing osmotic diuresis was obtained by the intravenous administration of large amounts of hypertonic mannitol solution together with ADH. Max. Uosm, solute excretion rate, and inulin clearance were determined.

\section{Experimental details.}

$A$ : The unanaesthetised dogs were placed in a special sling for these studies. Polythene catheters were inserted into either the saphenous or the femoral vein for infusion and into the femoral artery for sampling. The animals were given $25 \mathrm{ml}$ water $/ \mathrm{kg} \mathrm{b}$.w. at body temperature through a stomach tube and about 1.5 hours later inulin and $\mathrm{PAH}$ administration was begun. Initial doses and rates of infusion are listed in Table 1. A three per cent glucose solution at a rate of about $3 \mathrm{ml}$ per minute was given intravenously at the same time to maintain positive water balance. Urine volume (V) ranged from 2 to $5 \mathrm{ml}$ per minute during the experiments. At least 45 minutes elapsed between the time inulin or PAH infusions were begun and the first of the three or more experimental periods of about 20 minutes each. Plasma levels of inulin and PAH were determined in blood samples taken in the middle of each experimental period. A permanent Foley catheter was placed in the bladder and the bladder emptied by manual pressure after insufflation with air and rinsing with a known volume of physiological saline solution. The urine was collected in graduated vessels. 
$B$ : The method for determining max. Uosm has been described in detail in a previous report (Asheim $1963 \mathrm{~b}$ ). Each dog received an intramuscular injection of $5 \mathrm{U}$ pitressin tannate in oil $^{\star}$ ) immediately before the last three 60-minute periods. Urine was collected for each of the last five 60 -minute periods. The highest Uosm values attained are listed as max. Uosm in Table 3; urine volume for the same periods are included in the table.

GFR for four pyometra bitches was obtained by measuring endogenous creatinine clearance, i. e. urinary creatinine excretion for the last five 60 -minute periods, in relation to plasma creatinine levels during the corresponding periods.

GFR for the other pyometra bitches and the normal bitches was determined by inulin clearance during short periods immediately after the concentration studies and while the animals were still dehydrated. The animals were restrained and samples taken in the manner described under $A$. The amount of inulin administered is listed in Table 1. ADH (Pitressin ${ }^{\star}$ ) was given intravenously at the same time as inulin, initially as $50 \mathrm{mU}$ per $\mathrm{kg}$ bodyweight and subsequently as $30 \mathrm{mU}$ per $\mathrm{kg}$ bodyweight and hour. Infusion of 5 or 10 per cent mannitol solution with $100 \mathrm{mEq} \mathrm{NaCl}$ per litre was begun at the same time or 15 to 20 minutes later. The initial rate of infusion was 1 to $5 \mathrm{ml}$ per min. but this was gradually increased to $15-20 \mathrm{ml}$ per min. for the pyometra bitches and to $20-50 \mathrm{ml}$ per min. for the normal bitches. In order to attain equilibrium, at least 45 minutes elapsed before the inulin clearance studies were begun and if urine volume was then less than $1.5 \mathrm{ml}$ per min. the equilibrium period was prolonged until this volume was attained. The experimental periods generally lasted ten minutes but because of differences in rates of urine excretion the periods were sometimes as short as eight minutes or as long as 30 minutes. Blood samples were taken from the femoral artery mid-way through the longer periods or in the middle of every second or third short period. Insufflation of air helped to obtain complete emptying of the bladder. The values for GFR represent the mean $\mathrm{C}_{\text {In }}$ for four or more periods for each animal.

Max. Uosm and $V$ as well as $C_{\text {In }}$ were determined for the 15 normal bitches during the infusion of 20 to $50 \mathrm{ml}$ mannitol solution per min. The effect of the osmotic load upon max. Uosm and $\mathrm{V}$ was re-assessed for seven of the $\mathbf{1 5}$ normal bitches after an interval of at least three weeks. Together, the 22 experiments cover 119 experimental periods.

Inulin levels were determined by Josephson \& Godin's (1943) modification of Corcoran \& Page's method (1939), PAH levels by the method of Smith et al. (1945), and creatinine levels by Teger-Nilsson's (1961) method. The method of determining urine and plasma osmolarity by freezing-point depression has been described previously (Åsheim 1963 b).

*) Parke, Davis. 


\section{CALGULATIONS}

The method of Cowgill \& Drabkin (1927) has been used to calculate body surface area.

Uosm values for different animals ought to be compared at the same rates of solute excretion per unit functioning renal mass (Bricker et al. 1960, Kleeman et al. 1961). Solute excretion rate is the product of Uosm and V expressed as $\mu \mathrm{Osm} / \mathrm{min}$. Glomerular filtration has been used as a measure of functioning renal mass. The values obtained for solute excretion rate have been corrected to $100 \mathrm{GFR}$ according to the formula of Kleemann et al. (1961).

$\begin{aligned} \frac{100 \mathrm{GFR}}{\text { observed GFR }} & \times \text { observed rate of solute excretion }=\text { predicted rate } \\ & \text { of solute excretion per } 100 \mathrm{GFR}\left({ }_{1} \mu \mathrm{Osm} / \mathrm{min} .\right) .\end{aligned}$

\section{RESULTS}

I. Clearance studies.

Mean values and ranges for plasma levels of inulin and PAH after equilibration for at least 45 minutes are listed in Table 1.

Table 2 contains the clearance values for hydrated dogs. The results for the normal bitches were much the same as those obtained previously for a series of 32 normal dogs (Âsheim et al. 1961). The GFR values obtained for the pyometra bitches ranged from normal to greatly reduced. There was a statistically significant $(P<0.001)$ difference between the mean value for these bitches and the normal value. $\mathrm{C}_{\mathrm{PAH}}$, an expression of renal blood flow (ERPF), also varied greatly but there was no statistically significant difference in comparison with the normal values. Since the GFR for several bitches was reduced while the ERPF was normal or only slightly reduced, the filtration fraction (FF) for these bitches - i. e. the relation between GFR and ERPF was less than for normal bitches. The reduction in FF for the pyometra bitches was almost significant (Table 2, $0.05<\mathrm{P}<$ 0.01 ). The ranges for the pyometra and the normal bitches, however, overlapped.

GFR for the dehydrated animals are listed in Tables 3 to $5^{\star}$ ). The mean results obtained for the normal hydropenic bitches (Table 3) were much the same as those for the hydrated bitches - 73 and $75 \mathrm{ml} / \mathrm{min} . / \mathrm{m}^{2}$ respectively. GFR for the hydropenic pyometra bitches ranged from normal to greatly reduced levels (Table 4). The mean GFR was statistically significantly

*) $\mathrm{C}_{\text {In }}$ was fairly constant throughout the mannitol infusion. 


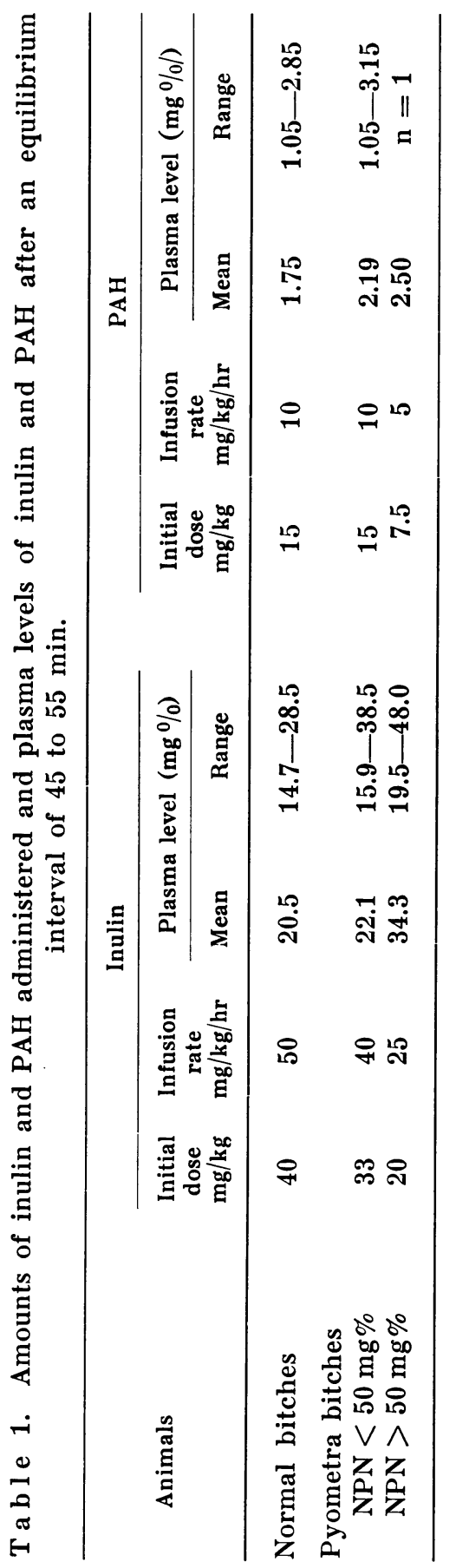


T a ble 2. GFR $\left(\mathrm{C}_{\text {In }}\right)$, ERPF $\left(\mathrm{C}_{\mathrm{PAH}}\right)$, and filtration fraction (FF) for pyometra bitches and normal bitches in positive water balance.

All values are expressed in relation to $1 \mathrm{~m}^{2}$ body surface.

\begin{tabular}{|c|c|c|c|c|c|c|c|}
\hline \multicolumn{4}{|c|}{ Normal bitches } & \multicolumn{4}{|c|}{ Pyometra bitches } \\
\hline No. & $\begin{array}{c}\mathrm{C}_{\mathrm{In}} \\
\mathrm{ml} / \mathrm{min} .\end{array}$ & $\begin{array}{c}\mathrm{C}_{\mathrm{PAH}} \\
\mathrm{ml} / \mathrm{min} .\end{array}$ & FF & No. & $\begin{array}{c}\mathrm{C}_{\mathrm{In}} \\
\mathrm{ml} / \mathrm{min}\end{array}$ & $\begin{array}{c}\mathrm{C}_{\mathrm{PAH}} \\
\mathrm{ml} / \mathrm{min} .\end{array}$ & FF \\
\hline $\mathrm{P} \quad 1$ & 67 & 204 & 0.33 & 2 & 70 & 406 & 0.17 \\
\hline $\mathrm{P} 6$ & 87 & 275 & 0.32 & 19 & 72 & 431 & 0.17 \\
\hline P 7 & 72 & 357 & 0.21 & 108 & 30 & 161 & 0.20 \\
\hline P 8 & 99 & 264 & 0.38 & 112 & 90 & 406 & 0.22 \\
\hline P 9 & 71 & 188 & 0.38 & 117 & 54 & 305 & 0.18 \\
\hline P 10 & 73 & 319 & 0.24 & 121 & 81 & 376 & 0.22 \\
\hline P 14 & 61 & 352 & 0.18 & 122 & 71 & 273 & 0.26 \\
\hline P 15 & 67 & 318 & 0.21 & 123 & 93 & 335 & 0.23 \\
\hline P 16 & 70 & 281 & 0.35 & 124 & 45 & 243 & 0.18 \\
\hline \multirow[t]{7}{*}{ P 17} & 83 & 284 & 0.37 & 126 & 82 & 205 & 0.38 \\
\hline & & & & 127 & 35 & 185 & 0.19 \\
\hline & & & & 128 & 54 & 319 & 0.17 \\
\hline & & & & 129 & $22 \dagger$ & 78 & 0.29 \\
\hline & & & & 130 & 79 & 369 & 0.32 \\
\hline & & & & 131 & 57 & 188 & 0.30 \\
\hline & & & & 132 & 57 & 205 & 0.28 \\
\hline Mean & $75 \pm 11^{\text {* }}$ & $284 \pm 56$ & $0.30 \pm 0.08$ & & $62 \pm 21$ & $280 \pm 104$ & $0.24 \pm 0.06$ \\
\hline $\begin{array}{l}\text { Range } \\
\text { P-yalue }\end{array}$ & $61-99$ & $188-357$ & $0.18-0.38$ & & $\begin{array}{c}22-93 \\
\mathrm{P}<0.001\end{array}$ & $\begin{array}{l}78-431 \\
P>0.05\end{array}$ & $\begin{array}{l}0.17-0.38 \\
0.05>P>0.01\end{array}$ \\
\hline P-value & & & & & $\mathrm{P}<0.001$ & $P>0.05$ & \\
\hline
\end{tabular}

†) $\mathrm{NPN}>50 \mathrm{mg} \%$

*) Mean \pm standard deviation

(P. $<0.001)$ lower than that for the normal hydropenic bitches. Four of the bitches included in Table 4 (no. 33, 44, 46, 47) had NPN values of over $50 \mathrm{mg}$ per $100 \mathrm{ml}$; these animals had the lowest GFR in the series.

Renal function studies during dehydration were repeated on some of the dogs 12 to 16 days after ovariohysterectomy. The post-operative GFR (Table 5) remained at the same level or improved and were only exceptionally lower than the pre-operative values. Bitch 33 can serve as an example of post-operative improvement. The pre-operative NPN was increased $(66 \mathrm{mg}$ per $100 \mathrm{ml}$ ). When examined 41 days after ovariohysterectomy, the GFR had increased from $32 \mathrm{ml} / \mathrm{min} . / \mathrm{m}^{2}$ to a fairly normal value of $61 \mathrm{ml} / \mathrm{min} . / \mathrm{m}^{2}$ and the NPN level had dropped to $35 \mathrm{mg}$ 
Table 3. Concentrating ability and the corresponding rates of solute excretion for normal bitches after dehydration for 24 hours and the administration of $5 \mathrm{U}$ pitressin tannate in oil. Glomerular filtration rate (GFR) was determined by inulin clearance.

\begin{tabular}{|c|c|c|c|c|c|c|c|}
\hline \multirow{2}{*}{$\begin{array}{l}\text { Normal } \\
\text { bitches } \\
\text { no. }\end{array}$} & \multirow{2}{*}{$\begin{array}{c}\text { Surface } \\
\text { area } \\
\mathrm{m}^{2}\end{array}$} & \multicolumn{2}{|c|}{$\begin{array}{l}\text { Glomerular } \\
\text { filtration rate }\end{array}$} & \multirow[t]{2}{*}{$\begin{array}{c}\text { Max. Uosm } \\
\mathrm{mOsm} / \mathbf{l}\end{array}$} & \multirow[t]{2}{*}{$\begin{array}{l}\text { Posm } \\
\text { mOsm/l }\end{array}$} & \multirow{2}{*}{$\begin{array}{l}\text { Solute excre- } \\
\text { tion rate } \\
\mu \text { Osm/min. }\end{array}$} & \multirow{2}{*}{$\begin{array}{l}\text { Predicted rate of } \\
\text { solute excretion } \\
\mu \text { Osm/min./ } \\
100 \mathrm{GFR}\end{array}$} \\
\hline & & $\mathrm{ml} / \mathrm{min}$ & $\mathrm{ml} / \mathrm{min} . / \mathrm{m}^{2}$ & & & & \\
\hline $\mathrm{P} 2$ & 0.70 & 47 & 67 & 1830 & 286 & 110 & 228 \\
\hline P 5 & 0.80 & 55 & 72 & 1660 & 304 & 199 & 344 \\
\hline P 6 & 0.61 & 33 & 54 & 1371 & 286 & 128 & 388 \\
\hline P 9 & 0.90 & 87 & 97 & 1466 & 302 & 323 & 371 \\
\hline P 12 & 1.03 & 100 & 97 & 1530 & 296 & 188 & 194 \\
\hline P 15 & 0.61 & 41 & 67 & 1404 & 286 & 183 & 446 \\
\hline P 17 & 0.77 & 64 & 83 & 1508 & 283 & 178 & 278 \\
\hline F 0 & 0.65 & 45 & 69 & 1501 & 294 & 195 & 433 \\
\hline F 7 & 0.79 & 57 & 72 & 1347 & 285 & 166 & 291 \\
\hline F 9 & 0.98 & 51 & 52 & 2092 & 302 & 190 & 373 \\
\hline F 10 & 0.74 & 63 & 85 & 1560 & 285 & 156 & 248 \\
\hline F 11 & 0.99 & 64 & 65 & 1500 & 294 & 192 & 300 \\
\hline F 12 & 0.75 & 62 & 83 & 1608 & 288 & 166 & 268 \\
\hline F 16 & 0.72 & 58 & 81 & 1898 & 305 & 190 & 328 \\
\hline F 18 & 0.66 & 38 & 58 & 1604 & 298 & 192 & 422 \\
\hline Mean & & & $73 \pm 14$ & 1592 & 293 & & \\
\hline
\end{tabular}

per $100 \mathrm{ml}$. In one bitch (no. 20), however, there was a great reduction in GFR after operation, from 79 to $44 \mathrm{ml} / \mathrm{min} . / \mathrm{m}^{2}$, but no change in NPN.

II. Max. Uosm in relation to solute excretion rate.

Changes in max. Uosm during a steadily increasing osmotic load have been followed for $\mathbf{1 5}$ dehydrated normal bitches in 22 experiments covering 119 experimental periods. Fig. 1 illustrates how the increase in osmotic load first leads to a rapid and then to a slower reduction in max. Uosm until the values approach Posm. The form of the curve can be expressed by the equation

$$
\mathrm{Y}=293+236600 \times \mathrm{X}^{-0.847}
$$

in which 293 represents the mean value expressed in mOsm/l for Posm of dehydrated normal bitches (Table 3). The lower portion of the curve forms an asymptote with the horizontal line representing plasma osmolarity and the upper portion of the curve appears to approach a vertical line representing a solute excretion rate between 460 and $470 \mu \mathrm{Osm} / \mathrm{min} . / 100 \mathrm{GFR}$. Lower 
Table 4. Concentrating ability and the corresponding rates of solute excretion for pyometra bitches after dehydration for 21 hours and the administration of $5 \mathrm{U}$ pitressin tannate in oil. Unless stated otherwise, GFR has been determined by inulin clearance.

\begin{tabular}{|c|c|c|c|c|c|c|c|}
\hline \multirow{2}{*}{$\begin{array}{c}\text { Pyometra } \\
\text { bitches } \\
\text { no. }\end{array}$} & \multirow{2}{*}{$\begin{array}{c}\text { Surface } \\
\text { area } \\
\mathrm{m}^{2}\end{array}$} & \multicolumn{2}{|c|}{$\begin{array}{l}\text { Glomerular } \\
\text { filtration rate }\end{array}$} & \multirow[t]{2}{*}{$\begin{array}{l}\text { Max. Uosm } \\
\text { mOsm/1 }\end{array}$} & \multirow[t]{2}{*}{$\begin{array}{c}\text { Posm } \\
\text { mOsm/1 }\end{array}$} & \multirow{2}{*}{$\begin{array}{l}\text { Solute excre- } \\
\text { tion rate } \\
\mu \text { Osm } / \mathrm{min} \text {. }\end{array}$} & \multirow{2}{*}{$\begin{array}{c}\text { Predicted rate of } \\
\text { solute excretion } \\
\mu \mathrm{Osm} / \mathrm{min} . / \\
100 \mathrm{GFR}\end{array}$} \\
\hline & & $\mathrm{ml} / \mathrm{min}$ & $\mathrm{ml} / \mathrm{min} . / \mathrm{m}^{2}$ & & & & \\
\hline 9 & 0.83 & 60 & 72 & 1076 & 296 & 267 & 445 \\
\hline 10 & 0.74 & 64 & 86 & 1050 & 297 & 103 & 161 \\
\hline 11 & 1.31 & $88^{\star}$ & 67 & 1029 & 302 & 233 & 265 \\
\hline 12 & 0.70 & 55 & 79 & 1024 & 282 & 118 & 215 \\
\hline 13 & 1.04 & 63 & 61 & 1022 & 289 & 205 & 325 \\
\hline 14 & 0.45 & 23 & 51 & 1008 & 295 & 87 & 378 \\
\hline 16 & 0.51 & $29^{\star}$ & 57 & 963 & 315 & 85 & 293 \\
\hline 17 & 0.59 & 32 & 54 & 919 & 303 & 147 & 459 \\
\hline 20 & 1.07 & 85 & 79 & 886 & 292 & 133 & 156 \\
\hline 21 & 0.44 & $25^{\star}$ & 57 & 873 & 289 & 74 & 296 \\
\hline 22 & 0.65 & 21 & 32 & 868 & 287 & 146 & 695 \\
\hline 28 & 1.13 & 61 & 54 & 740 & 296 & 180 & 295 \\
\hline 29 & 0.54 & 19 & 35 & 719 & 278 & 86 & 453 \\
\hline 30 & 0.63 & 58 & 92 & 715 & 309 & 139 & 240 \\
\hline 31 & 1.34 & 99 & 74 & 713 & 298 & 290 & 293 \\
\hline 32 & 0.67 & 54 & 80 & 708 & 304 & 248 & 459 \\
\hline 33 & 0.63 & $20 \dagger$ & 32 & 692 & 299 & 90 & 450 \\
\hline 34 & 0.56 & 25 & 45 & 662 & 301 & 131 & 524 \\
\hline 36 & 0.92 & 75 & 82 & 647 & 309 & 276 & 368 \\
\hline 38 & 0.89 & $44^{*}$ & 49 & 571 & 316 & 212 & 482 \\
\hline 39 & 0.47 & 19 & 41 & 562 & 294 & 84 & 442 \\
\hline 40 & 0.90 & 55 & 62 & 551 & 296 & 240 & 436 \\
\hline 43 & 0.95 & 43 & 45 & 518 & 314 & 192 & 447 \\
\hline 44 & 0.64 & $14 \dagger$ & 22 & 434 & 320 & 104 & 742 \\
\hline 46 & 0.73 & $20 \dagger$ & 27 & 417 & 294 & 160 & 800 \\
\hline 47 & 0.43 & $6 \dagger$ & 14 & 412 & 297 & 54 & 901 \\
\hline 50 & 1.13 & 56 & 50 & 340 & 300 & 238 & 425 \\
\hline 52 & 0.91 & 53 & 58 & 308 & 296 & 299 & 564 \\
\hline Mean & & & $\begin{array}{l}56 \pm 20 \\
P<0.00\end{array}$ & & & & \\
\hline
\end{tabular}

* Creatinine clearance

$\dagger \mathrm{NPN}>50 \mathrm{mg}$ per $100 \mathrm{ml}$

values for solute excretion rate do not seem to affect maximum concentrating ability which is governed by the max. Uosm for each animal. The mean max. Uosm for normal bitches at low rates of solute excretion is $1592 \mathrm{mOsm} / \mathrm{l}$ (Table 3) and is represented in Fig. 1 by a horizontal line. Intersection between that 
T a b l e 5. Changes in GFR, max. Uosm, and solute excretion rate in pyometra bitches after ovariohysterectomy.

\begin{tabular}{|c|c|c|c|c|c|c|c|c|}
\hline \multirow{2}{*}{$\begin{array}{l}\text { Pyometra } \\
\text { bitches } \\
\text { no. }\end{array}$} & \multirow{2}{*}{$\begin{array}{l}\text { Surface } \\
\text { area } \\
\text { m }^{2}\end{array}$} & \multirow{2}{*}{$\begin{array}{c}\text { Days } \\
\text { after } \\
\text { operation }\end{array}$} & \multicolumn{2}{|c|}{$\begin{array}{l}\text { Glomerular } \\
\text { filtration rate }\end{array}$} & \multirow{2}{*}{$\begin{array}{l}\text { Max. Uosm } \\
\text { mOsm/1 }\end{array}$} & \multirow[t]{2}{*}{$\begin{array}{l}\text { Posm } \\
\text { mOsm/1 }\end{array}$} & \multirow{2}{*}{$\begin{array}{c}\text { Solute excre- } \\
\text { tion rate } \\
\mu \text { Osm } / \mathrm{min} .\end{array}$} & \multirow{2}{*}{$\begin{array}{c}\text { Predicted rate of } \\
\text { solute exretion } \\
\mu \text { Osm/min./ } \\
100 \mathrm{GFR}\end{array}$} \\
\hline & & & $\mathrm{ml} / \mathrm{min}$ & $\mathrm{ml} / \mathrm{min} . / \mathrm{m}^{2}$ & & & & \\
\hline \multirow[t]{2}{*}{9} & 0.83 & 0 & 60 & 72 & 1076 & 296 & 267 & 445 \\
\hline & 0.85 & 116 & 72 & 85 & 1400 & 297 & 280 & 389 \\
\hline \multirow[t]{2}{*}{10} & 0.74 & 0 & 64 & 86 & 1050 & 297 & 103 & 161 \\
\hline & 0.74 & 12 & 73 & 100 & 1242 & 289 & 122 & 167 \\
\hline \multirow[t]{2}{*}{12} & 0.70 & $\mathbf{0}$ & 55 & 79 & 1024 & 282 & 118 & 215 \\
\hline & 0.70 & 14 & 54 & 77 & 797 & 308 & 184 & 341 \\
\hline \multirow[t]{2}{*}{16} & 0.51 & 0 & $29^{\star}$ & 57 & 963 & 315 & 85 & 293 \\
\hline & 0.49 & 13 & $31^{*}$ & 63 & 808 & 291 & 99 & 319 \\
\hline \multirow[t]{3}{*}{20} & 1.07 & 0 & 85 & 79 & 886 & 292 & 133 & 156 \\
\hline & 1.07 & 13 & 55 & 51 & 857 & 289 & 105 & 191 \\
\hline & 1.08 & 49 & 47 & 44 & 1326 & 288 & 110 & 234 \\
\hline \multirow[t]{2}{*}{21} & 0.44 & 0 & $25^{\star}$ & 57 & 873 & 289 & 74 & 296 \\
\hline & 0.44 & 14 & $29^{\star}$ & 69 & 1023 & 295 & 83 & 286 \\
\hline \multirow[t]{2}{*}{29} & 0.54 & 0 & 19 & 35 & 719 & 278 & 86 & 453 \\
\hline & 0.51 & 35 & 27 & 53 & 1262 & 288 & 124 & 459 \\
\hline \multirow[t]{2}{*}{33} & 0.63 & $\mathbf{0}$ & $20 \dagger$ & 32 & 692 & 299 & 90 & 450 \\
\hline & 0.63 & 41 & 38 & 61 & 1239 & 303 & 292 & 768 \\
\hline \multirow[t]{3}{*}{38} & 0.89 & 0 & $44^{\star}$ & 49 & 571 & 316 & 212 & 482 \\
\hline & 0.89 & 13 & $42^{\star}$ & 47 & 491 & 305 & 169 & 402 \\
\hline & 0.87 & 75 & $44^{\star}$ & 50 & 524 & 308 & 185 & 420 \\
\hline \multirow[t]{2}{*}{39} & 0.47 & 0 & 19 & 41 & 562 & 294 & 84 & 442 \\
\hline & 0.49 & 48 & 23 & 47 & 1550 & 307 & 149 & 648 \\
\hline \multirow[t]{2}{*}{40} & 0.90 & 0 & 55 & 62 & 551 & 296 & 240 & 436 \\
\hline & 0.86 & 12 & 55 & 64 & 596 & 291 & 184 & 335 \\
\hline \multirow[t]{2}{*}{43} & 0.95 & 0 & 43 & 45 & 518 & 314 & 192 & 447 \\
\hline & 0.94 & 41 & 43 & 45 & 1142 & 300 & 186 & 433 \\
\hline \multirow[t]{4}{*}{46} & 0.73 & 0 & $20 \dagger$ & 27 & 417 & 294 & 160 & 800 \\
\hline & 0.73 & 12 & 30 & 42 & 832 & 303 & 209 & 697 \\
\hline & 0.72 & 27 & 34 & 47 & 887 & 282 & 237 & 696 \\
\hline & 0.74 & 65 & 29 & 39 & 999 & 288 & 190 & 655 \\
\hline
\end{tabular}

* Creatinine clearance

$\dagger$ NPN $>50 \mathrm{mg}$ per $100 \mathrm{ml}$

line and the curve has been calculated statistically to occur at a solute excretion rate of $468 \mu \mathrm{Osm} / \mathrm{min} . / 100 \mathrm{GFR}$. The limits enclosing 80 per cent of the values are also indicated in Fig. 1.

Table 4 lists the values for max. Uosm and solute excretion rate for pyometra bitches after dehydration and the administration of exogenous ADH but without mannitol infusion. All bitches had lower max. Uosm values than normal. The predicted 


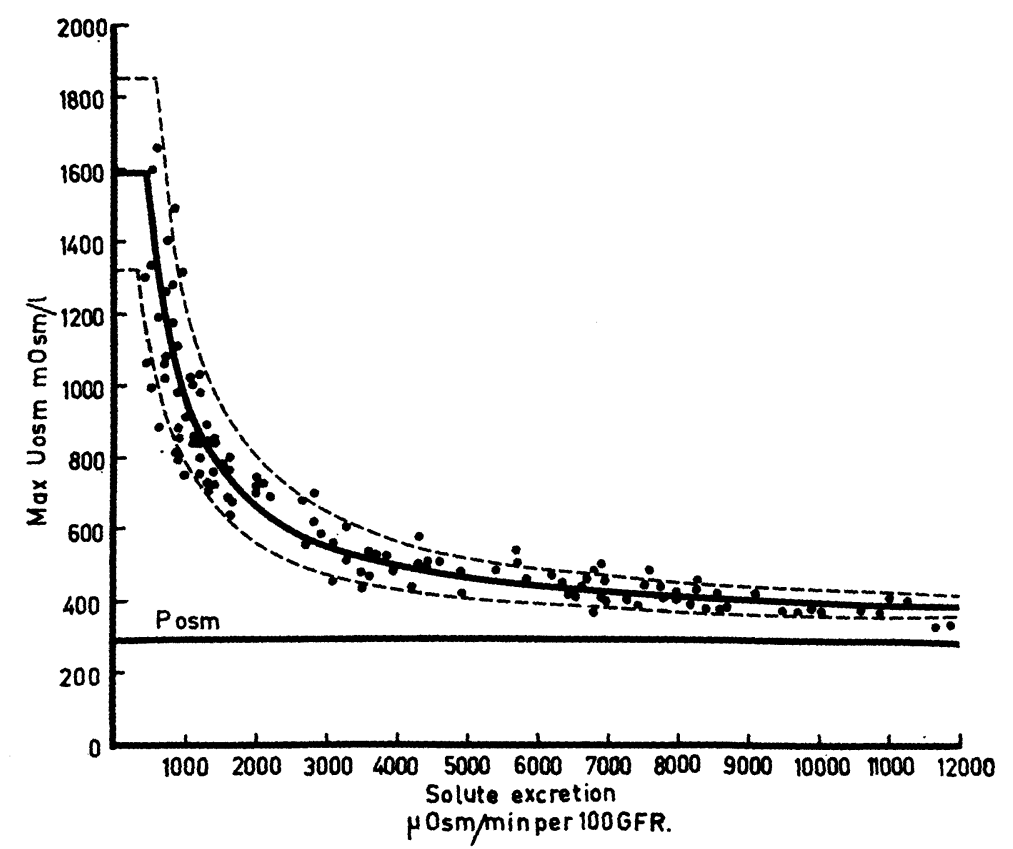

F i g. 1. Relation between max. Uosm and rates of solute excretion calculated per 100 GFR in normal dehydrated dogs subjected to an increasing osmotic load. The dashed lines on each side of the curve give the limits for 80 per cent of the values obtained.

rate of solute excretion for most of them was less than 468 $\mu \mathrm{Osm} / \mathrm{min} . / 100 \mathrm{GFR}$ and accords with that for normal bitches under the same experimental conditions (Table 3 ). The predicted rate of solute excretion for three of the four bitches with an elevated NPN level was increased to over $700 \mu \mathrm{Osm} / \mathrm{min} . / 100$ GFR. These three animals like the other pyometra bitches had a lower max. Uosm than normal bitches at the same rates of solute excretion (Fig. 2).

Max. Uosm values obtained after ovariohysterectomy were improved or normal in most instances (Table 5). Improvement was not apparently associated with changes in the solute excretion rate.

Two (no. 33, 46) of the four bitches with elevated NPN values were examined again after ovariohysterectomy. The absolute value for max. Uosm was still reduced for both animals but in comparison with normal bitches at the same rates of solute excretion, the concentrating ability of the remaining functioning nephrons was within normal limits (Fig. 3). 


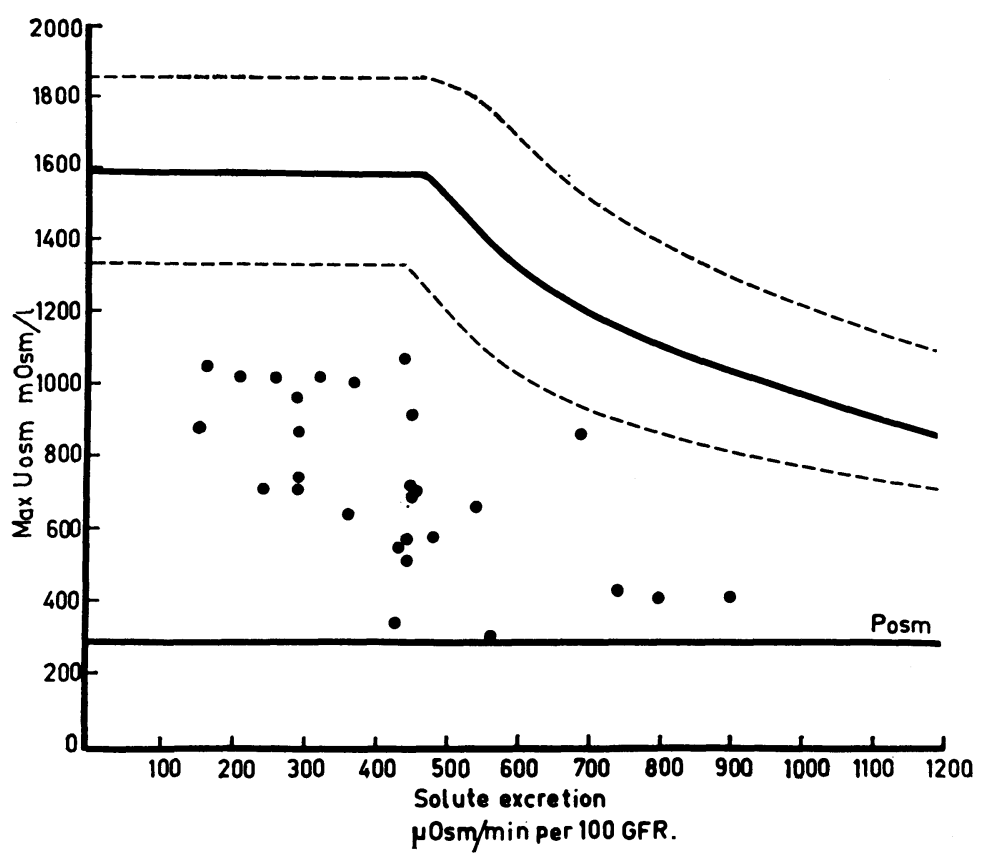

F i g. 2. Max. Uosm for pyometra bitches compared with max. Uosm for normal bitches (curves) at equivalent rates of solute excretion.

\section{DISCUSSION}

There are some points to be kept in mind when evaluating the results of these experiments.

a) The values for GFR obtained for hydrated animals are not fully comparable with those of dehydrated animals. Dehydration can lead to a reduction in GFR (Black et al. 1942) and increasing the osmotic load can give an increase in GFR (Wesson Jr. 1957). For this reason, results for the pyometra bitches have always been compared with results obtained for normal bitches under the same experimental conditions. The mean values for GFR, however, were 75 and $73 \mathrm{ml} / \mathrm{min} . / \mathrm{m}^{2}$ for the hydrated and dehydrated normal bitches respectively, a sign that the different experimental conditions did not greatly affect the results.

b) $\mathrm{PAH}$ extraction values $\left(\mathrm{E}_{\mathrm{PAH}}\right)$ were not determined for the pyometra bitches since the condition of these animals did not permit the protracted anaesthesia necessary for catheterization of the renal vein. The lack of a statistically significant difference between the ERPF values for the pyometra bitches 


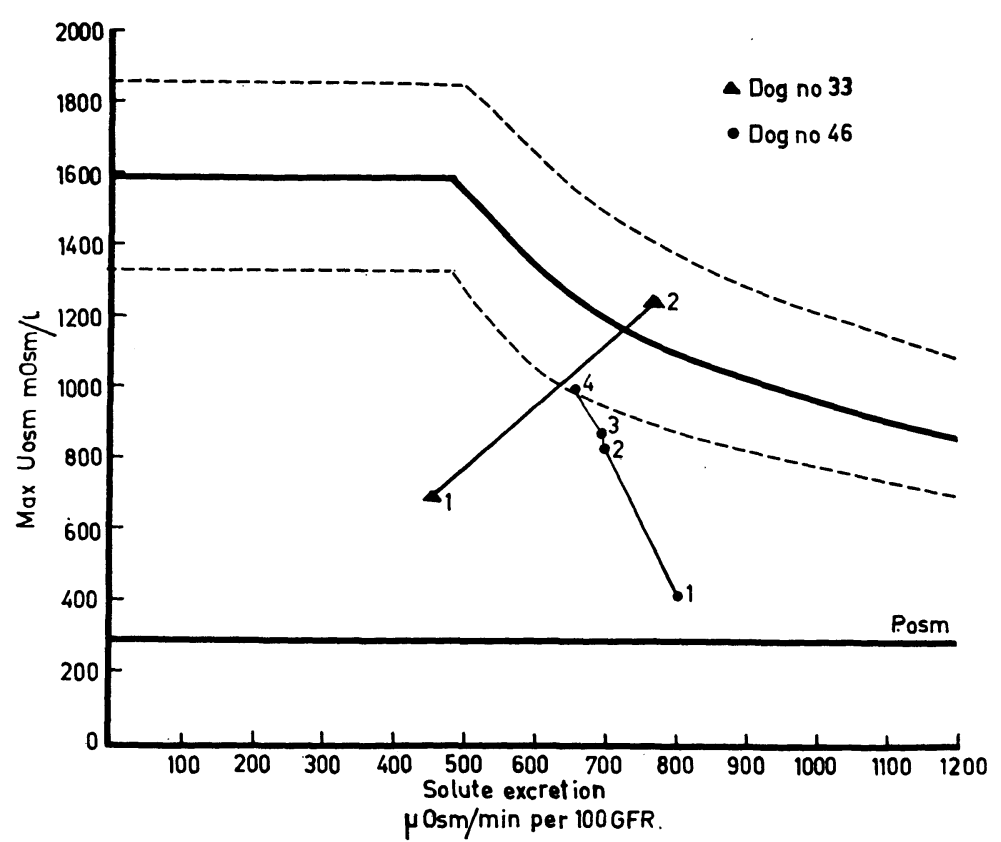

Fi g. 3. Max. Uosm before and after ovariohysterectomy for two pyometra bitches with increased NPN compared with max. Uosm for normal bitches (curves) at equivalent rates of solute excretion (see Table 5). The values given the two lines are numbered in the order in which they were obtained before and after operation.

and the normal animals suggests that the disturbance in renal function associated with pyometra does not include a reduction in $E_{P A H}$. If $E_{P A H}$ for the pyometra bitches was reduced, then the ERPF for this group should have been greater than that for the normal bitches. There was no evidence that this was the case.

c) The osmotic load on the functioning nephrons has been calculated on the basis of solute excretion rate per $100 \mathrm{GFR}$. The use of GFR as a measure of functioning renal mass presupposes that the filtration fraction, the ratio $\frac{\mathrm{C}_{\mathrm{In}}}{\mathrm{C}_{\mathrm{PAH}}}$, is normal. If the FF is reduced, the calculated values will be too high in relation to the actual values for the osmotic load on the tubules. Since there was a tendency towards a reduction in FF for the pyometra bitches and consequently towards too high values when calculating the osmotic loading on the tubules, there are greater 
grounds for concluding (see below) that the osmotic load on the functioning nephrons is low in pyometra.

The experimental results for the pyometra bitches lead to consideration of the following questions.

1. The experimental results suggest that there is a reduction in the functioning renal mass. Do the clearance studies indicate the nature of the renal damage?

2. In pyometra bitches there is generally a reduction in renal concentrating ability. Is this disturbance a result of a reduction in the functioning renal mass with a consequent osmotic diuresis because of an increased osmotic load carried by the residual functioning nephrons or has the reduction in concentrating ability another pathogenesis?

In reply to the first question, the tendency towards a reduction in filtration fraction which can be associated with pyometra suggests that the reduction in renal mass begins with glomerular damage. The normal $\mathrm{FF}$ values in bitches with severe renal dysfunction does not contradict this hypothesis since secondary tubular damage is known to follow upon glomerular damage.

The second question can best be answered by citing the following facts.

a) In most bitches with pyometra, the osmotic load on the functioning nephrons is lower than the lowest osmotic load which can induce osmotic diuresis of sufficient degree to affect max. Uosm in normal bitches (in spite of the osmotic load on the tubules probably being calculated too generously as mentioned above).

b) There is no obvious correlation between the degree of reduction in concentrating ability and reduction in GFR.

c) As the osmotic load per functioning nephron is increased, the reduction in concentrating ability becomes much greater than it would be if it were simply the result of osmotic diuresis.

d) The improvement in concentrating ability of a pyometra bitch after ovariohysterectomy is not usually matched by an improvement in clearance values.

All these considerations lead to the hypothesis that in some bitches with pyometra there can be such a reduction in functioning renal mass that osmotic diuresis probably occurs but that the characteristic reduction in renal concentrating ability mainly 
depends upon a functional abnormality in the parts of the kidney governing urine concentration and one which is independent of the osmotic load. Such an hypothesis would in fact accord with the observations of Franklin et al. (1959) and Kleemann et al. (1961) concerning the relation between osmotic load and concentrating ability in renal diseases in human beings.

\section{REFERENCES}

Åsheim, Å.: Renal function in dogs with pyometra. 1. Studies of the hypothalamic-neurohypophyseal system. Acta vet. scand. 1963 a, 4, $281-291$.

Åsheim, A.: Renal function in dogs with pyometra. 2. Concentrating and diluting ability. Acta vet. scand. $1963 \mathrm{~b}, 4,293-306$.

Åsheim, Å.: Persson, F. \& Persson, S.: Renal clearance in dogs with regard to variations according to age and sex. Acta physiol. scand. 1961, 31, 150-162.

Black, D. A. K., McCance, R. A. \& Young, W. F.: Function of the kidney in dehydration. Nature 1942, 150, 461.

Bloom, F.: Pathology of the dog and cat. 1954. Amer. Veterinary Public. Inc., Evanstone, Illinois.

Bricker, N. S., Morrin, A. F. \& Kime, S. W.: The pathologic physiology of chronic Bright's disease. Amer. J. Med. 1960, 28, 77-98.

Corcoran, A. C. \& Page, I. H.: Applications of diphenylamine in the determination of levulos in biological media. I. The determination of inulin. J. biol. Chem. 1939, 127, 601-608.

Cowgill, G. R. \& Drabkin, D. L.: Determination of a formula for the surface area of the dog together with a consideration of formulae available for other species. Amer. J. Physiol. 1927, 81, 36-61.

Dorhout Mees, E. J.: Role of osmotic diuresis in impairment of concentrating ability in renal disease. Brit. med. J. 1959, 1, 11561158.

Franklin, S. S., Neall, J. F.\& Merrill, J. P.: The influence of solute load on the isosthenuria of renal disease. J. clin. Invest. 1959, 38, 1005 .

Josephson, B. \& Godin, A. S.: Om bestämning av glomerulusfiltrationen. Nordisk Medicin 1943, 18, 893-897.

Kleeman, C. R., Adams, D. A. \& Maxwell, M. H.: An evaluation of maximal water diuresis in chronic renal disease. I. Normal solute intake. J. lab. \& clin. Med. 1961, 58, 169-184.

Kleemann, C. R., Hewitt, W. L. \& Guze, L. B.: Pyelonephritis. Medicine $1960,39,3-116$.

Page, L. B. \& Reem, G. H.: Urinary concentrating mechanism in the dog. Amer. J. Physiol. 1952, 171, 572-577.

Smith, H. W., Finkelstein, N., Aliminosa, L., Crawford, B. \& Graber, M.: The renal clearance of substituted hippuric acid derivates and other aromatic acids in dog and man. J. clin. Invest. 1945, 24, $388-404$. 
Teger-Nilsson, A. C.: Serum creatinine determination using an ion exchange resin. Scand. J. clin. \& lab. Invest. 1961, 13, 326-331.

Wesson Jr., L. G.: Glomerular and tubular factors in the renal excretion of sodium chloride. Medicine 1957, 36, 281-396.

West, C. D. \& Rapoport, S.: Urine flow and solute excretion of hydropenic dog under "resting" conditions and during osmotic diuresis. Amer. J. Physiol. 1950, 163, 159-174.

Zak, G. A., Brun, C. \& Smith, H. W.: The mechanism of formation of osmotically concentrated urine during the antidiuretic state. J. clin. Invest. $1954,33,1064-1074$.

\section{SUMMARY}

Renal function studies on bitches with pyometra and normal bitches have included determinations of glomerular filtration rate (GFR), effective renal plasma flow (ERPF), solute excretion rate per unit functioning renal mass, maximum urine osmolarity (max. Uosm), and - for the normal bitches - max. Uosm after increasing osmotic load with mannitol infusions.

GFR for the pyometra bitches varied from normal to greatly reduced values; the mean GFR was statistically significantly lower than that for normal bitches. There were also wide variations in ERPF; there was no significant deviation from normal values but the two pyometra bitches with the greatest reduction in GFR also had greatly reduced ERPF values. The ratio between GFR and ERPF (filtration fraction) varied within normal limits but there was a tendency towards reduction $(0.05<\mathrm{P}<0.01)$.

After dehydration the max. Uosm for all the pyometra bitches was below the lower limit for max. Uosm for normal bitches. The rates of solute excretion per unit functioning renal mass for most bitches with pyometra were less than the level $(468 \mu \mathrm{Osm} / \mathrm{min} . / 100$ GFR) above which the osmotic load begins to reduce max. Uosm in normal bitches. Even in those bitches in which the solute excretion rate reached values over $468 \mu \mathrm{Osm} / \mathrm{min} . / 100 \mathrm{GFR}$ (because of reduction in the number of functioning nephrons) max. Uosm was far below the max. Uosm values for normal dogs at the same rates of solute excretion. Consequently, in bitches with pyometra, factors other than osmotic diuresis appear to be mainly responsible for the reduction in concentrating ability and polyuria.

\section{ZUSAMMENFASSUNG}

Die Nierenfunktion bei Hunden mit Pyometra.

3. Glomerulumfiltration, Nierenplasmafluss und das Verhältnis zwischen Ausscheidung der osmotisch aktiven Substanzen und Konzentrationsfähigkeit.

Untersuchungen der Nierenfunktionen wurden an normalen Hunden und an Hunden mit Pyometra zur Bestimmung von Glomerulumfiltrat (GFR), Nierenplasmafluss (ERPF), Ausscheidung der osmú- 
tisch aktiven Substanzen per Einheit funktionierenden Nierengewebe, maximale Konzentrationsfähigkeit (max. Uosm) als auch betreffend normale Hunde die Bestimmung von Uosm bei stufenweise erhöhten osmotische Belastung durch Mannitol, unternommen.

Bei Hunden mit Pyometra variiert GFR von normalen bis stark gesunkenen Werten. Verglichen mit den Werten für normale Hunde, zeigt der Mittelwert von Hunden mit Pyometra eine statistisch gesicherte Senkung. Soeben zeigte ERPF grosse Variationen; der Mittelwert zeigte keine statistisch gesicherte Abweichung vom Normalmaterial, jedoch in beiden Fällen bei denen die grösste Reduktion des GFR vorkommt, bestand soeben eine hochgradige Senkung des ERPF. Das Verhälțis zwischen GFR und ERPF (Filtrationsfraktion) zeigt normale Variationen, jedoch ist es wahrscheinlich, dass eine Senkungstendenz vorliegt, da der Mittelwert für FF von Hunden mit Pyometra verglichen mit den Werten von normalen Hunden zeigt eine Senkung die signifikant wäre $(0,05<\mathrm{P}<0,01)$.

Nach der Dehydrierung lag max. Uosm für sämtliche Pyometrafälle unterhalb der unteren Grenze für max. Uosm bei normalen Hunden. Die Ausscheidungsgeschwindigkeit der osmotisch aktiven Substanzen per Einheit funktionierenden Nierengewebe befand sich in der Mehrzahl der Pyometrafälle unter der Grenze (468 $\mu$ Osm/Min./100 GFR), oberhalb welcher beginnt die Belastung bei normalen Hunden auf max. Uosm einzuwirken. Soeben in Fällen wo die Ausscheidungsgeschwindigkeit Werte über $468 \mu \mathrm{Osm} / \mathrm{Min}$./100 GFR erreichte (wegen der verminderten Anzahl der funktionierenden Nephrone), war max. Uosm weit unter den max. Uosm-Werte für normale Hunden bei der verglichenen Geschwindigkeiten der osmotischer Ausscheidung. Es ist möglich, dass bei den sämtlichen Hunden mit Pyometra, die Hauptursache für die Verminderung der Konzentrationsfähigkeit und für das Entstehen einer Polyurie, nicht die osmotische Diurese, sondern andere Faktoren von entscheidender Bedeutung sind.

\section{SAMMANFATTNING}

Njurfunktionen hos hundar med pyometra.

3. Glomerulifiltrationen och njurgenomblödningen samt relationen mellan utsöndringen av osmotiskt aktiva substanser och maximala koncentrationsförmågan.

Njurfunktionsstudier har företagits på normala hundar samt på hundar med pyometra för fastställande av glomerulifiltrationen (GFR), njurgenomblödningen (ERPF), utsöndringen av osmotiskt aktiva substanser per enhet funktionerande njurvävnad, maximala koncentrationsförmågan ( $\max$. Uosm) samt - för normalhundarnas vidkommande - max. Uosm vid successivt ökad osmotisk belastning med mannitol.

GFR varierar på pyometrahundarna från normala till kraftigt sänkta värden. Medeltalet för pyometrahundarna visar en statistiskt säkerställd sänkning $\mathrm{i}$ jämförelse med värdet för normalhundarna. 
ERPF visar även stora variationer; medelvärdet visar ingen statistiskt säker avvikelse från normalmaterialet men i de båda fall som företedde den största reduktionen av GFR förelåg en höggradig minskning även av ERPF. Trots att förhållandet mellan GFR och ERPF (filtrationsfraktionen) visar normala variationer tycks det föreligga en tendens till sänkning, då medelvärdet för FF för pyometrahundarna i jämförelse med det hos normalhundarna visar en minskning som är signifikant $(0,05<\mathrm{P}<0,01)$.

Max. Uosm efter dehydrering låg för samtliga pyometrafall nedanför den undre gränsen för max. Uosm på normalhundar. Utsöndringshastigheten av osmotiskt aktiva substanser per enhet funktionerande njurvävnad låg $i$ flertalet fall av pyometra under den gräns (468 $\mu$ Osm/min./100 GFR) ovanför vilken belastningen börjar påverka max. Uosm på normalhundar. Även i de fall där utsöndringshastigheten nått värden över $468 \mu \mathrm{Osm} / \mathrm{min} . / 100 \mathrm{GFR}$ (till följd av reduktion av antalet funktionerande nefron) låg max. Uosm långt under max. Uosm-värdena för normalhundar vid jämförbara hastigheter av den osmotiska utsöndringen. Hos samtliga pyometrahundar synes sålunda andra faktorer än en osmotisk diures spela huvudrollen för nedsättningen av koncentrationsförmågan och uppkomsten av polyurin.

(Received June 18. 1963). 